\title{
How Postdoctoral Research in Paul Greengard's Laboratory Shaped My Scientific Career, Although I Never Did Another Phosphorylation Assay
}

\author{
(1DAnnette C. Dolphin \\ Department of Neuroscience, Physiology and Pharmacology, University College London, London, WC1E 6BT, United Kingdom
}

In this short review, I describe from personal experience how every step in the career of any scientist, no matter how disjointed and pragmatic each might seem at the time, will almost inevitably meld together, to help us all tackle novel projects. My postdoctoral research in Paul Greengard's laboratory, where I investigated neurotransmitter-mediated phosphorylation of Synapsin I, was instrumental in my career progression, and Paul's support was instrumental in my ability to make a leap into independent research.

When the Society for Neuroscience was soliciting articles for its new journal, I was a postdoctoral fellow in Paul Greengard's laboratory, completing studies of neurotransmitter regulation of synapsin I phosphorylation. When Paul informed me that he been invited to contribute a paper, we knew it would be risky thing to volunteer one's precious data because this was an untested journal. But it came at a good time because I was about to leave the laboratory and had data that complemented my recently accepted paper demonstrating phosphorylation of the presynaptic protein Synapsin I (which we called Protein I at the time) by a neurotransmitter (Dolphin and Greengard, 1981b). So I was very happy to publish in the initial volume of the Journal of Neuroscience, which was to be the first of my 17 papers so far in the journal. The data published in 1981 extended my work on serotonin-mediated phosphorylation and also demonstrated phosphorylation by another class of neuromodulator, acting at adenosine receptors (Dolphin and Greengard, 1981a). It was such a pleasure for me to reread that paper, as it brought back many memories of life in the Greengard laboratory, together with colleagues and friends, including Pietro De Camilli, Angus Nairn, Wieland Huttner, Clive Palfrey, Eric Nestler, Suzanne Lohmann, Ulrich Walter, Howard Schulman, Mary Kennedy, and many others.

My interest in intracellular signaling pathways activated by neurotransmitters began when I was an undergraduate student in Biochemistry; I wrote a dissertation on cyclic AMP in prokaryotes and eukaryotes, and then conducted an undergraduate research project examining glycine as a neurotransmitter, using spinal cord synaptosomes as an experimental preparation. This interest propelled me toward Parkinson's disease research as a graduate student in the laboratory of the neurologist David

Received Dec. 7, 2020; revised Jan. 21, 2021; accepted Jan. 26, 2021.

The author declares no competing financial interests.

This work was supported by multiple grants from the United Kingdom Medical Research Council and the

Wellcome Trust during my career. I thank Eric Nestler for reading an earlier version of this manuscript.

Correspondence should be addressed to Annette C. Dolphin at a.dolphin@ucl.ac.uk.

https://doi.org/10.1523/JNEUROSCI.3002-20.2021

Copyright $\odot 2021$ the authors
Marsden at the Institute of Psychiatry in London, where I examined the importance of dopaminergic and noradrenergic pathways in animal models of Parkinson's disease. I then wrote to Paul Greengard, asking to do postdoctoral research under his mentorship, because I knew I needed more basic training in cell signaling pathways, since my $\mathrm{PhD}$ environment had been very focused on translational and clinical research. I could not think of anywhere better than Paul's laboratory because of his seminal work on cyclic nucleotide signaling pathways (Beam and Greengard, 1976). He said his laboratory was full, but agreed to take me in a year's time, subject to interview. Fortunately, I had also obtained a UK Medical Research Council French exchange fellowship to work in the laboratory of Joel Bockaert, at College de France in Paris, where I studied the coupling between $\beta$-adrenergic receptors and adenylate cyclase. This valuable experience cemented my desire to continue research in this area and work with Paul Greengard. Thus it was that Paul, on a visit to Paris, invited me to be interviewed in his hotel room. I was on my guard when I knocked on the door, and a voice called out to come in. As I entered, I could see nothing but a large bed, but I soon located Paul lying flat on the floor beyond; he explained it was because of his chronic back problem. I perched on the bed, and tried to answer his searching scientific questions. I later realized that Paul lay on the floor at every opportunity, often in our laboratory meetings and indeed during other interviews (Nestler, 2019).

When I arrived in Paul's laboratory then at Yale, in the summer of 1978, the protein Synapsin I had recently been identified as a major presynaptic phosphoprotein (Ueda and Greengard, 1977). It was then called "Protein 1" because it stood out as the main polypeptide in synaptosomes that was phosphorylated in both a cAMP- and a $\mathrm{Ca}^{2+}$-dependent manner (Sieghart et al., 1979). However, no neurotransmitters had yet been found to influence the phosphorylation of Synapsin I, and to identify such a pathway seemed to be the holy grail at the time. Paul's world view of multiple signaling cascades terminating in the phosphorylation of many different target proteins, that would underlie long-term 

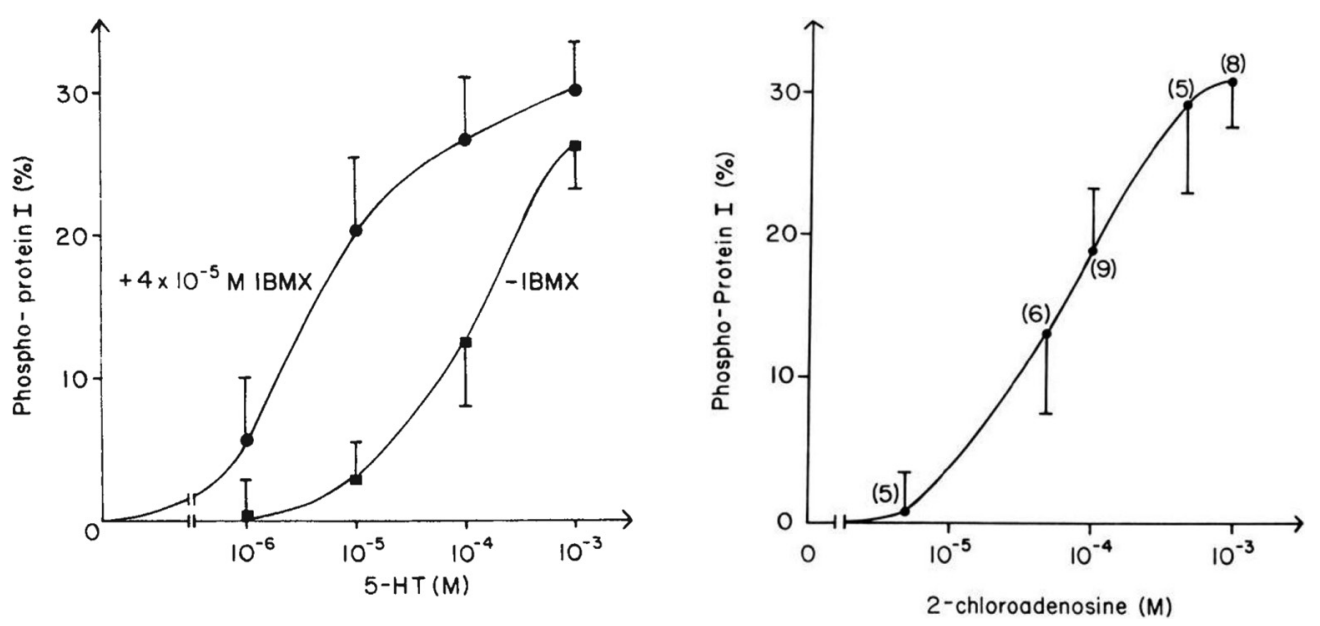

Figure 1. Phosphorylation of Synapsin I by actions at serotonin and adenosine receptors. Stimulation of Synapsin I (then called Protein I) phosphorylation with serotonin in the presence and absence of IBMX (left) (from Dolphin and Greengard, 1981b, our Fig. 2) or 2-choloroadenosine (right) (from Dolphin and Greengard, 1981a, our Fig. 4). The "back phosphorylation" method was used, in which ${ }^{32}$ P-ATP together with catalytic subunit of protein kinase A were used to phosphorylate residual nonphosphorylated sites on Synapsin I.

synaptic events, was often at odds with the then prevailing view of ion channel biologists, that neurotransmission was mediated by fast neurotransmitters acting on ion channels, a process in which there was no need to consider neurochemical mechanisms. Eric Kandel (from an electrophysiological standpoint), and Paul, from the basis of biochemical pathways, were both key to the acceptance of the view that a multitude of biochemical pathways must play a role in longer term events. Indeed, Paul was collaborating with Eric Kandel's laboratory at that time to elucidate whether a phosphorylation cascade mediated the effects of serotonin (5-HT) in Aplysia, and many of us in the laboratory were very influenced by these elegant studies, combining, as they did, electrophysiology and biochemical approaches (Castellucci et al., 1980, 1982).

Paul suggested that my project should be to examine whether neurotransmitters could change the state of phosphorylation of Synapsin I in the brain, but he left it entirely to me what tissue I should use for my study. There were $\sim 25$ postdocs and students in his laboratory at the time, and so I had a lot of help and advice, although Paul was the opposite of a micro-manager. Influenced both by the work of Eric Kandel and that of my previous mentor Joel Bockaert (Enjalbert et al., 1978), I decided that serotonin would be a good neurotransmitter to study. Taking inspiration from the work of George Aghajanian, also a professor in the Pharmacology Department at Yale, whose studies had revealed the effects of serotonin on many types of neuron (Aghajanian et al., 1990), I chose to examine the tiny facial nucleus in the brainstem, since Aghajanian had extensively examined the electrophysiological properties of this nucleus, as well as its ultrastructure (Aghajanian and McCall, 1980). His work indicated the facial nucleus had no interneurons, and therefore I thought it might lead to a more homogeneous phosphorylation response than many other brain areas. Indeed, serotonin did result in an increase in phosphorylation of Synapsin I in this preparation, but I initially found that the effects were small and very variable (Fig. 1, left). This was disappointing, and I remember blaming myself for being a cackhanded experimenter.

A breakthrough came indirectly through family tragedy; my father died in 1979, and I returned to England for the funeral. Fortuitously, I also decided to investigate potential future positions in the UK, and visited Leslie Iversen's Medical Research Council unit in Cambridge. While there, I showed my underwhelming phosphorylation data to John Dowling, who was on sabbatical in the unit at the time, working on dopamine-sensitive adenylate cyclase activity in the retina (Watling et al., 1979). I asked his advice and remember clearly that he suggested adding a low concentration of a phosphodiesterase inhibitor to the slices to potentiate the cAMP response to serotonin. On my return, I duly added isobutyl-methyl-xanthine (IBMX) to the facial nucleus slices, and the responses became much more robust (Dolphin and Greengard, 1981b) (Fig. 1, left). Similarly, Eric Nestler also found that dopamine and depolarization increased the phosphorylation of Synapsin I in superior cervical ganglion neurons (Nestler and Greengard, 1980).

Something I could not understand in my data was that the serotonin-mediated phosphorylation of Synapsin I was $\mathrm{Ca}^{2+}$-dependent, whereas the phosphorylation mediated by stimulation of an adenosine receptor was not. This was the main topic of my follow-up paper in the first volume of Journal of Neuroscience (Dolphin and Greengard, 1981a) (Fig. 1, right). Everyone in the laboratory remembers that writing papers with Paul was exhausting, as we considered multiple versions of every sentence, and these were written and rewritten in pencil with many erasures. But I can still hear his voice in every phrase of this Journal of Neuroscience paper, and it remains a pleasure to reread each well-considered argument, for which I take absolutely no credit.

In the Discussion, many possibilities are suggested to explain the surprising $\mathrm{Ca}^{2+}$ dependence of the serotonin-stimulated phosphorylation, and these points remain relevant, even now. For example, we point out that, in Aplysia neurons, serotonin stimulated a presynaptic adenylate cyclase, and this increased the influx of $\mathrm{Ca}^{2+}$ (Shimahara and Tauc, 1977; Klein and Kandel, 1978). We suggested that both processes might contribute to presynaptic Synapsin I phosphorylation. I also wonder now if we were seeing a combined effect of 5HT3 receptor activation, allowing $\mathrm{Ca}^{2+}$ entry, and subsequent $\mathrm{Ca}^{2+}$-calmodulin (CaM) kinase-dependent phosphorylation of Synapsin I, as well as activation of presynaptic serotonergic GPCRs that directly stimulated adenylate cyclase. Of course, the existence of $5 \mathrm{HT} 3$ receptors, which are $\mathrm{Ca}^{2+}$-permeable ion channels, and the many subtypes of G-protein-coupled 5-HT receptors was unknown at the time (Raymond et al., 2001).

My study of neurotransmitter-dependent phosphorylation of Synapsin I was cut short because of family problems that called me back to the UK. But work on Synapsin I simultaneously involved many others in Paul's laboratory, so research on its 
subcellular localization and function continued apace. For example, Wieland Huttner and Mary Kennedy both contributed to unraveling the process of $\mathrm{Ca}^{2+}$-dependent phosphorylation of Synapsin I (Huttner et al., 1981; Kennedy and Greengard, 1981). Indeed, cAMP-dependent protein kinase and CaM kinase both phosphorylated the same site on Synapsin I, and CaM kinase also phosphorylated additional sites (Huttner et al., 1981). Pietro De Camilli showed in elegant immuno-electron microscopic studies that Synapsin I was a cytoplasmic protein that was associated with synaptic vesicles (De Camilli et al., 1983). To date, there are over 2000 studies involving Synapsin I listed in PubMed, identifying its roles in synaptic function and pathology. These include many from Paul's own laboratory, continuing throughout his career (Hilfiker et al., 2005; Venton et al., 2006).

When I returned to UK, I had the good fortune to obtain a staff position at the Medical Research Council's National Institute of Medical Research (NIMR) at Mill Hill in London. This was an institution that Paul knew well, since he had spent a postdoctoral period in Wilhelm Feldberg's department at NIMR in the 1950s, recording from sympathetic nerve fibers. I find it fascinating that Paul was already interested in phosphorylation even then (Greengard and Straub, 1959a, 1959b). My post came about entirely through Paul's suggestion and generosity: he wrote to Arnold Burgen, then the Director of the Institute, whom he must have known from his work on cholinergic transmission. Suddenly and miraculously, I was offered a job, during a period when Margaret Thatcher was Prime Minister, the UK was in a deep recession, and academic positions were few and far between.

Before arriving, I knew very little about NIMR, and was thrilled to be appointed into the same Division of Neurophysiology and Neuropharmacology, which had previously housed the Yale triumvirate of Paul Greengard, Murdoch Ritchie, and Bill Douglas, and which currently contained an eclectic and exciting mix of groups studying pain, hearing, epilepsy, and hippocampal LTP. Wilhelm Feldberg also still had a laboratory there, and used to call me Delphine. I was, however, supernumerary, and given a small cupboard to work in, and an even smaller research consumables budget. In that environment, since I had become intrigued by presynaptic events, I decided to examine neurotransmitter release, and its modulation by activation of presynaptic receptors, including those activated by adenosine agonists, building on my knowledge of the very robust response of Synapsin I phosphorylation (Dolphin, 1983; Dolphin and Archer, 1983). I also rapidly developed an enjoyable collaboration with Tim Bliss and members of his group, including Mick Errington, working with them to measure field potentials and examine glutamate release from the dentate gyrus during the induction of LTP (Dolphin et al., 1982).

Studying the regulation of neurotransmitter release naturally led me to further questions about regulation of the $\mathrm{Ca}^{2+}$ influx that triggers this release, but this was not something I could directly address at NIMR. Although it did not feel like it at the time, it was fortuitous that the rules for obtaining tenure changed while I was there, meaning that to apply for tenure I would have to reapply for my position and then remain untenured for another 5 years. Many of the affected staff started to look for university posts, and I was offered a lectureship at St. George's Hospital Medical School, in the Department of Pharmacology. The interview went well, apart from being asked if I intended to have children, and I moved there in 1983, hoping again to pivot my research in a new direction. At that time, the Department was almost entirely populated by electrophysiologists, including the Head of Department, John Kelly, together with Vincenzo Crunelli, Mark Mayer, and Tom Bolton.
In this environment, it would be feasible for me to study voltage-gated calcium channels and their modulation by neurotransmitters, and how this related to neurotransmitter release. Ironically, while I was at Yale, Richard Tsien was on the faculty in the Physiology department, doing beautiful work on cardiac electrophysiology, leading up to an understanding of how cAMP modulates cardiac calcium channels, and the existence of additional calcium channels in neurons (Bean et al., 1984; Nowycky et al., 1985). However, my main memory of Dick Tsien at the time was that he adjudicated on my Yale postdoctoral fellowship application. When I started investigating calcium channels, I very belatedly wished I had concentrated better during Physiology seminars at Yale, to take advantage of their wealth of knowledge. Nevertheless, through the enormous generosity particularly of John Kelly at St. George's, I was able to learn how to record calcium currents in DRG neurons, which had already been established as a model to study presynaptic events (Dunlap and Fischbach, 1978). Together with my first postdoctoral research assistant and great friend, Rod Scott, we started to apply the same techniques to examine the mechanism of modulation of action potentials and calcium currents in these neurons by neurotransmitters, where we showed inhibition, particularly by activation of GABA-B and adenosine receptors (Dolphin et al., 1986).

Tools were initially lacking to study the role of $G$ proteins in the modulation of calcium channels and neurotransmitter release, but this changed for me when I visited Pietro De Camilli in Milan and attended the Fifth International Conference on Cyclic Nucleotides and Protein Phosphorylation, in July 1983. There I heard about the use of pertussis toxin to distinguish between different GTP binding protein mechanisms. Although it was not yet available commercially, I managed to locate a local source of pertussis toxin (entailing rather scary visits to the UK government Center for Applied Microbiology \& Research at Porton Down, where research on dangerous toxins and pathogens was conducted). Using both pertussis toxin and nonhydrolyzable guanine nucleotide analogs (including photoactivatable forms, made by John Wootton and David Trentham at NIMR), we then investigated the involvement of pertussis toxin-sensitive $G$ proteins in the modulation of both glutamate release (Dolphin and Prestwich, 1985) and calcium currents (Dolphin et al., 1986; Scott and Dolphin, 1986; Dolphin et al., 1988).

One of the next big scientific questions was to examine the same modulatory processes using the calcium channel subunits that were being cloned at that time by several groups (Tanabe et al., 1987; Ellis et al., 1988; De Jongh et al., 1990; Mori et al., 1991; Starr et al., 1991; Williams et al., 1992). In 1989, I was asked to apply for the Chair of Pharmacology at the Royal Free Hospital School of Medicine in London, and there I reoriented our efforts to examine the role of specific calcium channel subunits in the modulation of native and cloned calcium currents by $\mathrm{G}$ proteins. In our work, we concentrated initially on the role of the calcium channel $\beta$ subunits (Berrow et al., 1995). We then uncovered an essential role for the $\mathrm{N}$-terminus of $\mathrm{Ca}_{\mathrm{V}} 2$ calcium channels in their G-protein modulation (Page et al., 1998; Canti et al., 1999), and we demonstrated the importance of calcium channel $\beta$ subunits in the G-protein modulation of $\mathrm{Ca}_{\mathrm{V}} 2.2$ channels (Meir et al., 2000; Leroy et al., 2005), and also in PI3 kinase-mediated calcium channel modulation (Viard et al., 2004).

At that time, very little work had been done on the role of the intriguing $\alpha_{2} \delta$ subunits of calcium channels, whose topology and function were initially unclear (Brickley et al., 1995; Gurnett et al., 1996). We started working on these proteins through 
another fortunate encounter. When the Royal Free School of Medicine was merged with University College London (UCL), I was asked to move to the UCL Gower Street campus in 1997, primarily to free up my space for Professor Geoff Burnstock, who had relinquished his role as Head of Department of Anatomy at UCL. There, I had the good fortune to collaborate with Michele Rees in the Pediatrics Department, on the molecular basis for the Ducky mouse mutation, that causes absence epilepsy and ataxia. The mutation turned out to be in a calcium channel auxiliary subunit gene, Cacna2d2, encoding $\alpha_{2} \delta-2$ (Barclay et al., 2001). This work fortuitously led us on to an extended series of studies on the biochemistry, physiology, and pharmacology of the $\alpha_{2} \delta$ subunit family, about which little was then known. These investigations allowed me to combine my interests in biochemistry, from my undergraduate years, with all the many other techniques we have embraced, including electrophysiology. Among our findings were that the von Willebrand factor domain of $\alpha_{2} \delta$ subunits is essential for their ability to augment calcium currents (Canti et al., 2005; Hoppa et al., 2012; Dahimene et al., 2018), that $\alpha_{2} \delta$ proteins are anchored to the plasma membrane via a glycosyl-phosphatidyl inositol linkage rather by a transmembrane domain (Davies et al., 2010), that the $\alpha_{2} \delta$ subunits increase trafficking of calcium channels to the cell surface (Cassidy et al., 2014), and that proteolytic cleavage of $\alpha_{2} \delta$ into $\alpha_{2}$ and $\delta$ is an essential molecular switch for the augmentation of calcium currents and transmitter release (Kadurin et al., 2016; Ferron et al., 2018).

Other studies, including work from our own laboratory, found that $\alpha_{2} \delta-1$ mRNA and protein are strongly upregulated in DRG neurons in rodent models of neuropathic pain (Luo et al., 2001; Newton et al., 2001; Bauer et al., 2009). Furthermore, $\alpha_{2} \delta-1$ is the main receptor for the antiepileptic drug gabapentin, which is also of therapeutic benefit in neuropathic pain (Gee et al., 1996). We contributed to showing that their binding to $\alpha_{2} \delta-1$ is essential for the action of gabapentinoids to alleviate neuropathic pain (Field et al., 2006). Since $\alpha_{2} \delta$ proteins are auxiliary subunits, the molecular mechanism of action of these drugs in neuropathic pain was not immediately obvious, until we showed that gabapentinoids reduced calcium currents chronically, but not acutely, through an inhibitory effect on $\alpha_{2} \delta$ trafficking, both in vitro (Hendrich et al., 2008; Tran-Van-Minh and Dolphin, 2010) and in vivo (Bauer et al., 2009). We then found, by making a functional extracellularly tagged version of $\mathrm{Ca}_{\mathrm{V}} 2.2$, that as a consequence, gabapentin also reduced the trafficking and cell surface expression of the channel itself (Cassidy et al., 2014). A knock-in mouse containing this tagged $\mathrm{Ca}_{\mathrm{V}} 2.2$ is now allowing us to identify that $\alpha_{2} \delta-1 \mathrm{KO}$ also reduces the cell surface localization of $\mathrm{Ca}_{\mathrm{V}} 2.2$ in DRGs and their presynaptic terminals in vivo (Nieto-Rostro et al., 2018).

The molecular mechanisms involved in the development and maintenance of neuropathic pain are the subject of research of many groups (for review, see Sexton et al., 2018; Alsaloum et al., 2020; Halievski et al., 2020). As a result of orienting our research toward the involvement of calcium channels in neuropathic pain, I encountered another unexpected advantage of moving to UCL. We have been able to benefit enormously from the knowledge and advice of the many experts in pain who work there, including John Wood, Tony Dickenson, and Maria Fitzgerald. It is remarkable that, during my time at UCL, threads from my past have been picked up and helped to shape my work. Indeed, we have collaborated extensively with Tony Dickenson, who was one of the other nontenured staff scientists who left NIMR at the same time as me, and who then obtained a lectureship directly at

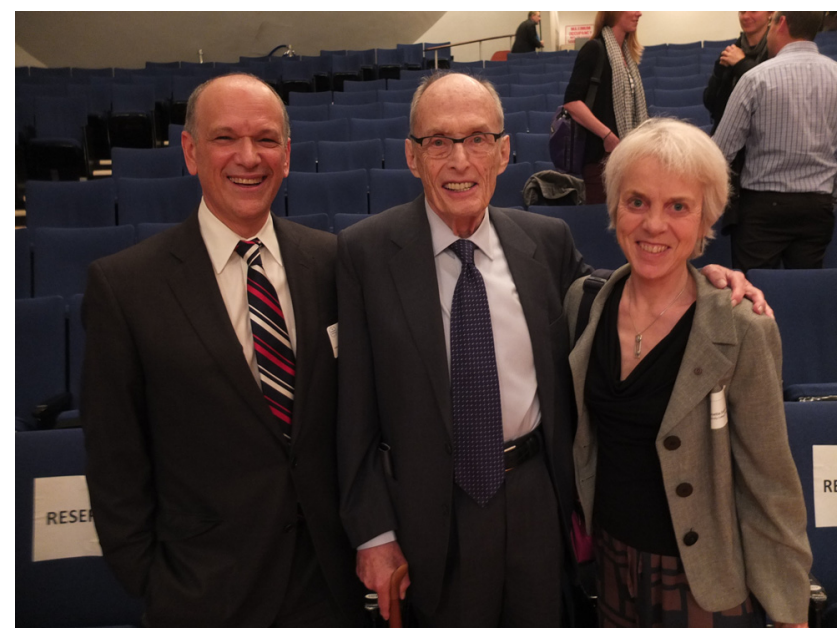

Figure 2. Eric Nestler, Paul Greengard, Annette Dolphin; December 11, 2015 at Paul's 90 th birthday celebration.

UCL (Bauer et al., 2009; Patel et al., 2013). Similarly, in an extension of the Greengard family, we had a valuable collaboration with Tim Ryan, who has also worked extensively with Paul Greengard's laboratory, particularly on the role of Synapsins in vesicular release (Ryan et al., 1996; Chi et al., 2003). With Tim, we studied the role of $\alpha_{2} \delta$ proteins in presynaptic $\mathrm{Ca}^{2+}$ entry and vesicular release (Hoppa et al., 2012), and this led us on to further examining the role of proteolytic cleavage of $\alpha_{2} \delta$ in these processes (Kadurin et al., 2016; Ferron et al., 2018).

I was honored to speak at Paul's 80th birthday celebration, and then also to attend his 90th birthday symposium, both held at Rockefeller University, where I was very happy to meet up with so many previous colleagues (Fig. 2). At the latter meeting, I also had the privilege of being able to tell Paul of my election to the Royal Society, and to thank him for his support; and I could see his real pleasure in this news. Although I have never worked directly on Synapsins since leaving Paul's laboratory, from these and other meetings, I have of course retained a keen interest in Paul's wide-ranging research, maintained until his death at age 93 in 2019. His work unraveling the enormous complexity of the many pathways involving neuronal protein phosphorylation, and their physiological and pathologic roles (Hilfiker et al., 1999; Svenningsson et al., 2004; Brichta and Greengard, 2014), contributed to his being awarded the Nobel Prize in 2000, together with Arvid Carlsson and Eric Kandel.

For younger scientists, I have only a few messages. Like me, I hope you will find that all your scientific studies and experience will be of benefit in the long run, even if you change fields, and all your scientific mentors, colleagues, and friends will remain important throughout your career; but the value of chance, casual conversations, and fortuitous meetings cannot be overstated. Treasure them all.

\section{References}

Aghajanian GK, McCall RB (1980) Serotonergic synaptic input to facial motoneurons: localization by electron-microscopic autoradiography. Neuroscience 5:2155-2162.

Aghajanian GK, Sprouse JS, Sheldon P, Rasmussen K (1990) Electrophysiology of the central serotonin system: receptor subtypes and transducer mechanisms. Ann NY Acad Sci 600:93-103; discussion 103.

Alsaloum M, Higerd GP, Effraim PR, Waxman SG (2020) Status of peripheral sodium channel blockers for non-addictive pain treatment. Nat Rev Neurol 16:689-705. 
Barclay J, Balaguero N, Mione M, Ackerman SL, Letts VA, Brodbeck J, Canti C, Meir A, Page KM, Kusumi K, Perez-Reyes E, Lander ES, Frankel WN, Gardiner RM, Dolphin AC, Rees M (2001) Ducky mouse phenotype of epilepsy and ataxia is associated with mutations in the Cacna2d2 gene and decreased calcium channel current in cerebellar Purkinje cells. J Neurosci 21:6095-6104.

Bauer CS, Nieto-Rostro M, Rahman W, Tran-Van-Minh A, Ferron L, Douglas L, Kadurin I, Sri Ranjan Y, Fernandez-Alacid L, Millar NS, Dickenson AH, Lujan R, Dolphin AC (2009) The increased trafficking of the calcium channel subunit alpha2delta-1 to presynaptic terminals in neuropathic pain is inhibited by the alpha2delta ligand pregabalin. J Neurosci 29:4076-4088.

Beam KG, Greengard P (1976) Cyclic nucleotides, protein phosphorylation and synaptic function. Cold Spring Harb Symp Quant Biol 40:157-168.

Bean BP, Nowycky MC, Tsien RW (1984) $\beta$-adrenergic modulation of calcium channels in frog ventricular heart cells. Nature 307:371-375.

Berrow NS, Campbell V, Fitzgerald EG, Brickley K, Dolphin AC (1995) Antisense depletion of $\beta$-subunits modulates the biophysical and pharmacological properties of neuronal calcium channels. J Physiol (Lond) 482:481-491.

Brichta L, Greengard P (2014) Molecular determinants of selective dopaminergic vulnerability in Parkinson's disease: an update. Front Neuroanat $8: 152$.

Brickley K, Campbell V, Berrow N, Leach R, Norman RI, Wray D, Dolphin AC, Baldwin S (1995) Use of site-directed antibodies to probe the topography of the $\alpha_{2}$ subunit of voltage-gated $\mathrm{Ca}^{2+}$ channels. FEBS Lett 364:129-133.

Canti C, Page KM, Stephens GJ, Dolphin AC (1999) Identification of residues in the $\mathrm{N}$-terminus of $\alpha 1 \mathrm{~B}$ critical for inhibition of the voltage-dependent calcium channel by G $\beta \gamma$. J Neurosci 19:6855-6864.

Canti C, Nieto-Rostro M, Foucault I, Heblich F, Wratten J, Richards MW, Hendrich J, Douglas L, Page KM, Davies A, Dolphin AC (2005) The metal-ion-dependent adhesion site in the Von Willebrand factor-A domain of $\alpha 2 \delta$ subunits is key to trafficking voltage-gated $\mathrm{Ca}^{2+}$ channels. Proc Natl Acad Sci USA 102:11230-11235.

Cassidy JS, Ferron L, Kadurin I, Pratt WS, Dolphin AC (2014) Functional exofacially tagged $\mathrm{N}$-type calcium channels elucidate the interaction with auxiliary alpha2delta-1 subunits. Proc Natl Acad Sci USA 111:8979-8984.

Castellucci VF, Kandel ER, Schwartz JH, Wilson FD, Nairn AC, Greengard P (1980) Intracellular injection of the catalytic subunit of cyclic AMP-dependent protein kinase simulates facilitation of transmitter release underlying behavioral sensitization in Aplysia. Proc Natl Acad Sci USA 77:7492-7496

Castellucci VF, Nairn A, Greengard P, Schwartz JH, Kandel ER (1982) Inhibitor of adenosine $3^{\prime}: 5^{\prime}$-monophosphate-dependent protein kinase blocks presynaptic facilitation in Aplysia. J Neurosci 2:1673-1681.

Chi P, Greengard P, Ryan TA (2003) Synaptic vesicle mobilization is regulated by distinct synapsin I phosphorylation pathways at different frequencies. Neuron 38:69-78.

Dahimene S, Page KM, Kadurin I, Ferron L, Ho DY, Powell GT, Pratt WS, Wilson SW, Dolphin AC (2018) The $\alpha_{2} \delta$-like protein Cachd 1 increases $\mathrm{N}$-type calcium currents and cell surface expression and competes with $\alpha_{2} \delta$-1. Cell Rep 25:1610-1621.

Davies A, Kadurin I, Alvarez-Laviada A, Douglas L, Nieto-Rostro M, Bauer CS, Pratt WS, Dolphin AC (2010) The $\alpha 2 \delta$ subunits of voltage-gated calcium channels form GPI-anchored proteins, a post-translational modification essential for function. Proc Natl Acad Sci USA 107:1654-1659.

De Camilli P, Harris SM Jr, Huttner WB, Greengard P (1983) Synapsin I (Protein I), a nerve terminal-specific phosphoprotein: II. Its specific association with synaptic vesicles demonstrated by immunocytochemistry in agarose-embedded synaptosomes. J Cell Biol 96:1355-1373.

De Jongh KS, Warner C, Catterall WA (1990) Subunits of purified calcium channels: alpha2 and delta are encoded by the same gene. J Biol Chem 265:14738-14741.

Dolphin AC (1983) The adenosine agonist 2-chloroadenosine inhibits the induction of long-term potentiation of the perforant path. Neurosci Lett 39:83-89.

Dolphin AC, Archer ER (1983) An adenosine agonist inhibits and a cyclic AMP analogue enhances the release of glutamate but not GABA from slices of rat dentate gyrus. Neurosci Lett 43:49-54.
Dolphin AC, Greengard P (1981a) Neurotransmitter- and neuromodulatordependent alterations in phosphorylation of protein I in slices of rat facial nucleus. J Neurosci 1:192-203.

Dolphin AC, Greengard P (1981b) Serotonin stimulates phosphorylation of protein I in the facial motor nucleus of rat brain. Nature 289:76-79.

Dolphin AC, Prestwich SA (1985) Pertussis toxin reverses adenosine inhibition of neuronal glutamate release. Nature 316:148-150.

Dolphin AC, Errington ML, Bliss TVP (1982) Long-term potentiation of the perforant path in vivo is associated with increased glutamate release. Nature 297:496-498.

Dolphin AC, Forda SR, Scott RH (1986) Calcium-dependent currents in cultured rat dorsal root ganglion neurones are inhibited by an adenosine analogue. J Physiol 373:47-61.

Dolphin AC, Wootton JF, Scott RH, Trentham DR (1988) Photoactivation of intracellular guanosine triphosphate analogues reduces the amplitude and slows the kinetics of voltage-activated calcium channel currents in sensory neurones. Pflugers Arch 411:628-636.

Dunlap K, Fischbach GD (1978) Neurotransmitters decrease the calcium component of sensory neurone action potentials. Nature 276:837-839.

Ellis SB, Williams ME, Ways NR, Brenner R, Sharp AH, Leung AT, Campbell KP, McKenna E, Koch WJ, Hui A, Schwartz A, Harpold MM (1988) Sequence and expression of mRNAs encoding the $\alpha_{1}$ and $\alpha_{2}$ subunits of a DHP-sensitive calcium channel. Science 241:1661-1664.

Enjalbert A, Bourgoin S, Hamon M, Adrien J, Bockaert J (1978) Postsynaptic serotonin-sensitive adenylate cyclase in the central nervous system: I. Development and distribution of serotonin and dopamine-sensitive adenylate cyclases in rat and guinea pig brain. Mol Pharmacol 14:2-10.

Ferron L, Kadurin I, Dolphin AC (2018) Proteolytic maturation of alpha2delta controls the probability of synaptic vesicular release. Elife 7:e37507.

Field MJ, Cox PJ, Stott E, Melrose H, Offord J, Su TZ, Bramwell S, Corradini L, England S, Winks J, Kinloch RA, Hendrich J, Dolphin AC, Webb T, Williams D (2006) Identification of the $\alpha 2 \delta$-1 subunit of voltage-dependent calcium channels as a novel molecular target for pain mediating the analgesic actions of pregabalin. Proc Natl Acad Sci USA 103:1753717542 .

Gee NS, Brown JP, Dissanayake VU, Offord J, Thurlow R, Woodruff GN (1996) The novel anticonvulsant drug, gabapentin (Neurontin), binds to the $\alpha_{2} \delta$ subunit of a calcium channel. J Biol Chem 271:5768-5776.

Greengard P, Straub RW (1959a) Restoration by barium of action potentials in sodium-deprived mammalian B and C fibres. J Physiol 145:562-569.

Greengard P, Straub RW (1959b) Effect of frequency of electrical stimulation on the concentration of intermediary metabolites in mammalian nonmyelinated fibres. J Physiol 148:353-361.

Gurnett CA, De Waard M, Campbell KP (1996) Dual function of the voltage-dependent $\mathrm{Ca}^{2+}$ channel $\alpha_{2} \delta$ subunit in current stimulation and subunit interaction. Neuron 16:431-440.

Halievski K, Ghazisaeidi S, Salter MW (2020) Sex-dependent mechanisms of chronic pain: a focus on microglia and P2X4R. J Pharmacol Exp Ther 375:202-209.

Hendrich J, Van Minh AT, Heblich F, Nieto-Rostro M, Watschinger K, Striessnig J, Wratten J, Davies A, Dolphin AC (2008) Pharmacological disruption of calcium channel trafficking by the alpha2delta ligand gabapentin. Proc Natl Acad Sci USA 105:3628-3633.

Hilfiker S, Pieribone VA, Czernik AJ, Kao HT, Augustine GJ, Greengard P (1999) Synapsins as regulators of neurotransmitter release. Philos Trans R Soc Lond B Biol Sci 354:269-279.

Hilfiker S, Benfenati F, Doussau F, Nairn AC, Czernik AJ, Augustine GJ, Greengard P (2005) Structural domains involved in the regulation of transmitter release by synapsins. J Neurosci 25:2658-2669.

Hoppa MB, Lana B, Margas W, Dolphin AC, Ryan TA (2012) alpha2delta expression sets presynaptic calcium channel abundance and release probability. Nature 486:122-125.

Huttner WB, DeGennaro LJ, Greengard P (1981) Differential phosphorylation of multiple sites in purified protein I by cyclic AMP-dependent and calcium-dependent protein kinases. J Biol Chem 256:1482-1488.

Kadurin I, Ferron L, Rothwell SW, Meyer JO, Douglas LR, Bauer CS, Lana B, Margas W, Alexopoulos O, Nieto-Rostro M, Pratt WS, Dolphin AC (2016) Proteolytic maturation of $\alpha 2 \delta$ represents a checkpoint for activation and neuronal trafficking of latent calcium channels. Elife 5:e21143.

Kennedy MB, Greengard P (1981) Two calcium/calmodulin-dependent protein kinases, which are highly concentrated in brain, phosphorylate protein I at distinct sites. Proc Natl Acad Sci USA 78:1293-1297. 
Klein M, Kandel ER (1978) Presynaptic modulation of voltage-dependent $\mathrm{Ca}^{2+}$ current: mechanism for behavioral sensitization in Aplysia californica. Proc Natl Acad Sci USA 75:3512-3516.

Leroy J, Richards MW, Richards MS, Butcher AJ, Nieto-Rostro M, Pratt WS, Davies A, Dolphin AC (2005) Interaction via a key tryptophan in the I-II linker of N-type calcium channels is required for betal but not for palmitoylated beta2, implicating an additional binding site in the regulation of channel voltage-dependent properties. J Neurosci 25:6984-6996.

Luo ZD, Chaplan SR, Higuera ES, Sorkin LS, Stauderman KA, Williams ME, Yaksh TL (2001) Upregulation of dorsal root ganglion $\alpha_{2} \delta$ calcium channel subunit and its correlation with allodynia in spinal nerve-injured rats. J Neurosci 21:1868-1875.

Meir A, Bell DC, Stephens GJ, Page KM, Dolphin AC (2000) Calcium channel $\beta$ subunit promotes voltage-dependent modulation of $\alpha 1 \mathrm{~B}$ by $\mathrm{G} \beta \gamma$. Biophys J 79:731-746.

Mori Y, Friedrich T, Kim MS, Mikami A, Nakai J, Ruth P, Bosse E, Hofmann F, Flockerzi V, Furuichi T, Mikoshiba K, Imoto K, Tanabe T, Numa S (1991) Primary structure and functional expression from complementary DNA of a brain calcium channel. Nature 350:398-402.

Nestler EJ (2019) Personal reflections on a mentor extraordinaire: Paul Greengard, Ph.D. (1925-2019). Neuropsychopharmacology 44:18371838.

Nestler EJ, Greengard P (1980) Dopamine and depolarizing agents regulate the state of phosphorylation of protein I in the mammalian superior cervical sympathetic ganglion. Proc Natl Acad Sci USA 77:7479-7483.

Newton RA, Bingham S, Case PC, Sanger GJ, Lawson SN (2001) Dorsal root ganglion neurons show increased expression of the calcium channel alpha2delta-1 subunit following partial sciatic nerve injury. Brain Res Mol Brain Res 95:1-8.

Nieto-Rostro M, Ramgoolam K, Pratt WS, Kulik A, Dolphin AC (2018) Ablation of alpha2delta-1 inhibits cell-surface trafficking of endogenous $\mathrm{N}$-type calcium channels in the pain pathway in vivo. Proc Natl Acad Sci USA 115:E12043-E12052.

Nowycky MC, Fox AP, Tsien RW (1985) Three types of neuronal calcium channel with different calcium agonist sensitivity. Nature 316:440-446.

Page KM, Canti C, Stephens GJ, Berrow NS, Dolphin AC (1998) Identification of the amino terminus of neuronal $\mathrm{Ca}^{2+}$ channel $\alpha 1$ subunits $\alpha 1 \mathrm{~B}$ and $\alpha 1 \mathrm{E}$ as an essential determinant of $\mathrm{G}$ protein modulation. J Neurosci 18:4815-4824.

Patel R, Bauer CS, Nieto-Rostro M, Margas W, Ferron L, Chaggar K, Crews K, Ramirez JD, Bennett DL, Schwartz A, Dickenson AH, Dolphin AC (2013) $\alpha 2 \delta$-1 gene deletion affects somatosensory neuron function and delays mechanical hypersensitivity in response to peripheral nerve damage. J Neurosci 33:16412-16426.
Raymond JR, Mukhin YV, Gelasco A, Turner J, Collinsworth G, Gettys TW, Grewal JS, Garnovskaya MN (2001) Multiplicity of mechanisms of serotonin receptor signal transduction. Pharmacol Ther 92:179-212.

Ryan TA, Li L, Chin LS, Greengard P, Smith SJ (1996) Synaptic vesicle recycling in synapsin I knock-out mice. J Cell Biol 134:1219-1227.

Scott RH, Dolphin AC (1986) Regulation of calcium currents by a GTP analogue: potentiation of (-)-baclofen-mediated inhibition. Neurosci Lett 69:59-64.

Sexton JE, Cox JJ, Zhao J, Wood JN (2018) The genetics of pain: implications for therapeutics. Annu Rev Pharmacol Toxicol 58:123-142.

Shimahara T, Tauc L (1977) Cyclic AMP induced by serotonin modulates the activity of an identified synapse in Aplysia by facilitating the active permeability to calcium. Brain Res 127:168-172.

Sieghart W, Forn J, Greengard P (1979) $\mathrm{Ca}^{2+}$ and cyclic AMP regulate phosphorylation of same two membrane-associated proteins specific to nerve tissue. Proc Natl Acad Sci USA 76:2475-2479.

Starr TV, Prystay W, Snutch TP (1991) Primary structure of a calcium channel that is highly expressed in the rat cerebellum. Proc Natl Acad Sci USA 88:5621-5625.

Svenningsson P, Nishi A, Fisone G, Girault JA, Nairn AC, Greengard P (2004) DARPP-32: an integrator of neurotransmission. Annu Rev Pharmacol Toxicol 44:269-296.

Tanabe T, Takeshima H, Mikami A, Flockerzi V, Takahashi H, Kangawa K, Kojima M, Matsuo H, Hirose T, Numa S (1987) Primary structure of the receptor for calcium channel blockers from skeletal muscle. Nature 328:313-318.

Tran-Van-Minh A, Dolphin AC (2010) The alpha2delta ligand gabapentin inhibits the Rab11-dependent recycling of the calcium channel subunit alpha2delta-2. J Neurosci 30:12856-12867.

Ueda T, Greengard P (1977) Adenosine 3':5'-monophosphate-regulated phosphoprotein system of neuronal membranes: I. Solubilization, purification, and some properties of an endogenous phosphoprotein. J Biol Chem 252:5155-5163.

Venton BJ, Seipel AT, Phillips PE, Wetsel WC, Gitler D, Greengard P, Augustine GJ, Wightman RM (2006) Cocaine increases dopamine release by mobilization of a synapsin-dependent reserve pool. J Neurosci 26:3206-3209.

Viard P, Butcher AJ, Halet G, Davies A, Nurnberg B, Heblich F, Dolphin AC (2004) PI3K promotes voltage-dependent calcium channel trafficking to the plasma membrane. Nat Neurosci 7:939-946.

Watling KJ, Dowling JE, Iversen LL (1979) Dopamine receptors in the retina may all be linked to adenylate cyclase. Nature 281:578-580.

Williams ME, Feldman DH, McCue AF, Brenner R, Velicelebi G, Ellis SB, Harpold MM (1992) Structure and functional expression of $\alpha_{1}, \alpha_{2}$, and $\beta$ subunits of a novel human neuronal calcium channel subtype. Neuron 8:71-84. 